\title{
US energy department backs down on plan for A-bomb victim studies
}

Washington and Tokyo. The US Department of Energy has reversed its controversial plan to strip the National Academy of Sciences (NAS) of responsibility for managing Radiation Effects Research Foundation (RERF) in Japan, which carries out longterm studies of the effects of the atomic bombs dropped on Japan during the Second World War.

RERF scientists had reacted with fury to a letter from the DoE letter ascribing its plan to the alleged secrecy of RERF's work. In response, the DoE said on Monday that the academy contract to manage RERF would be extended for two years, while an "international committee of distinguished scientists" assesses RERF's work.

Earlier this year, the DoE caused uproar among radiation scientists in Japan and the United States by announcing plans to transfer the academy's responsibility for the US side of the RERF, which is based in Hiroshima and jointly financed by Japan and the United States, to a US university or group of universities (see Nature 374, 490; 1995).

This month, Hazel O'Leary, the US energy secretary, said that she would drop the academy as manager of the programme, a role which it has held since 1947 , claiming that this was being done because of the ending of the Cold War and her desire to move away from secret research on the biological effects of radiation.

"The need for secret research on the biological effects of radiation has ended," she wrote to Bruce Alberts, president of the academy, on 14 June. "The worldwide interest in radiation health issues has grown beyond the concerns that provoked the armed services to ask [US President] Truman to appoint the academy in 1947."

But Tara O'Toole, assistant secretary for environment, safety and health, spoke with Alberts this week and agreed to extend the academy's contract for at least two years. Steven Galson, chief medical officer at the energy department, said the abrupt reversal followed "an incredible outpouring of concern about the decision to go with a university contractor".

In a statement suggesting that DoE's vacillation on the issue may reflect sharp divisions of opinion within the department, Galson added that the O'Leary letter was "not trying to imply that [the academy] and RERF were doing secret research".

US and Japanese researchers at RERF in Hiroshima are angry at the suggestion that their research is secret. "RERF does not engage in secret research," say Dale Preston, head of RERF's department of statistics, and Kiyohiko Mabuchi, head of the department of epidemiology.

They say that the foundation's work "has been and continues to be more public than any other study of radiation effects". They add that "this interpretation illustrates DoE's continued misunderstanding of the nature of the work at RERF, and [the academy's] role in these studies".

Before the policy reversal, one energy department official said that the RERF had never shaken off the influence of its origins as the Atomic Bomb Casualty Commission (ABCC), which, he pointed out, was established primarily to provide the US atomic bomb programme with secret information on the effects of exposure to radiation.

The official said that the early mission of the $\mathrm{ABCC}$ had been "absolutely without question" to perform secret research to benefit the weapons programme. Despite opening up later - especially after 1975 , when the commission accepted Japanese funding and became RERF - he said it had remained "isolated from the mainstream of public health research".

He cited the experience of Alice Stewart, a prominent, if controversial, British cancer expert, who has long challenged various official conclusions about the impact of exposure to radiation, and who he said had been denied "open and free access" to RERF data during the 1980s.

O'Leary is engaged in a highly public campaign to disentangle the Department of Energy and other US government agencies from secret radiation experiments, both past and present. The campaign has brought her department into sharp conflict with other agencies, including the Department of
Defense and the National Institutes of Health.

Itsuzo Shigematsu, chairman of RERF, says he is "surprised" by O'Leary's letter, and speculates that her view is based on events surrounding the early days of the ABCC. He also says that it is "completely wrong" for DoE officials to suggests that RERF has denied Stewart access to data.

But Preston acknowledges that some raw data was withheld from Stewart, claiming that this was on the grounds that sharing it "would violate the privacy of victims." Nevertheless, he claims that RERF has recently been "very responsive" to Stewart and other outside researchers, and describes charges that the foundation has been isolated from other research efforts as "outrageous". Preston suggests that the real motivation for the proposed change in management responsibility is the DoE's desire to save money.

O'Leary's comments were sent in response to a letter of 28 April from Alberts forwarding a resolution passed by the academy in protest at DoE's plans, and referring to widespread objections from the scientific community in Japan and the United States to the planned reorganization.

In April, the RERF Science Council, a binational group of scientists responsible for the foundation's scientific programme, also expressed concern about the plans. It called on the department to defer any decision on restructuring until the foundation's activities have been reviewed by an external team of experts. The Department of Energy now says it accepts the council's recommendation for such a review.

Colin Macilwain \& David Swinbanks

\section{French physicists attack bomb tests}

London. French scientists have mounted a series of protests against their government's decision to resume nuclear testing in the South Pacific atoll of Mururoa after a four-year suspension.

Last week, the National Union of Scientists issued a public statement condemning the decision, and numerous petitions are being circulated in the scientific community demanding that the underground tests should not be resumed.

The French Academy of Sciences, many of whose members have supported the protests as individuals, also debated the issue earlier this week, although by the end of the meeting no decision had been reached on whether to issue a formal

\section{IMAGE UNAVAILABLE FOR COPYRIGHT REASONS}

declaration on the resumption of tests.

France has been testing nuclear weapons at Mururoa since 1966, with tests being carried out underground since 1974 . The tests were suspended in 1992, but the new French President, Jacques Chirac, has now announced that eight further tests will be 